\title{
Working-Class Agency and Racial Inequality
}

\section{BRUCE NELSON}

To have one's work in progress dissected at length by two historians whose scholarship one admires is gratifying; it offers a refreshing opportunity to learn through critical dialogue. I am especially grateful to Thomas Sugrue for his reading of my article on "Class, Race and Democracy in the CIO". I agree with his assertion that "working-class racism was structured by forces over which workers had varying degrees of control". His focus on the "power of capital in shaping patterns of discrimination" is important and necessary, as is his attention to the role of larger, often unseen, social forces in constraining the choices that workers made. Sugrue's work on the intractability of discriminatory labor markets, corporate policy and capital flight, and the volatile convergence of black migration and the politics of housing in post-World War II Detroit is exemplary in many ways. Labor historians, especially those like myself who have focused on the "shop floor" and the internal dynamics of unions, have much to learn from his approach. ${ }^{2}$

However, to some degree Sugrue has misconstrued the purpose of my article. I never meant to imply that a focus on the agency of white workers can provide a full explanation of racial discrimination in employment, nor would I be willing to dismiss "economic explanations of labor market segmentation", as he suggests. Any in-depth study of racially-based inequalities must pay attention to exactly the themes that Sugrue so eloquently articulates. But my purpose in "Class, Race and Democracy in the CIO" was more limited. I focused on working-class agency because it has been a major preoccupation of labor historians since the early 1960s, and I wanted to engage the "new" labor history on its own terrain. Above all, I wanted to challenge certain assumptions that I believe have been at the heart of much of the new labor history, and that have - until recently - been at the heart of my own work. All of this required a focus on agency, without suggesting that the consciousness and activity of working people is either fully autonomous or sufficient as an explanation of racial inequality.

Take the post-war context in which the CIO sought to organize the South and expand labor's political role in shaping the direction of social

'See Thomas Sugnee, "The Structure of Urban Poverty: The Reorganization of Space and Work in Three Periods of American History", in Michael B. Katz (ed.), The "Underclass" Debate: Views from History (Princeton, 1993), pp. 85-117; idem, "CrabgrassRoots Politics: Race, Rights, and the Reaction against Liberalism in the Urban North, 1940-1964", Journal of American History, 82 (1995), pp. 551-578; idem, "'Forget Your Inalienable Right to Work': Deindustrialization and Its Discontents at Ford, 1950-1953", International Labor and Working-Class History, 48 (1995), pp. 112-130.

International Review of Social History 41 (1996), pp. 407-420 
policy. The CIO failed to achieve either of these objectives, but not because working-class agency determined the outcome. As Sugrue rightly points out, the institutional weight of the forces that stood over against labor's agenda was enormous. Powerful corporations like General Motors united with smaller, family-owned firms to contain union power and reassert management's "right to manage". Government at the state and local level was often hostile to unions. At the federal level the Truman administration was, at best, a clumsy and irresolute ally; Truman's own tirades played an important role in crystallizing popular antagonism toward "Big Labor". Meanwhile, the corporate campaign to sell "free enterprise" was creating waves of ideological backlash that merged with the rising tide of McCarthyism. Quite apart from the CIO's strategic miscalculations, these forces may well have been sufficient to defeat Operation Dixie. ${ }^{2}$

But the fact that this outcome was determined by larger, external forces does not make questions of working-class agency and consciousness insignificant - certainly not for labor historians. A successful campaign to organize the South would have required a heightened sense of working-class solidarity in the face of the corporate-led counteroffensive. Instead, issues of race and radicalism served to reinforce the existing fault lines that divided working people. Employers and their strategically placed allies would have played the "race" and "red" cards anyway, but in this case they planted their poisonous seeds in fertile soil. For the war had given renewed impetus to the struggle for civil rights and to the Great Migration. As these overflowing streams threatened to inundate well-defined racial boundaries, many whites concluded that only subversion could be at the root of the turmoil. Thus Barbara Griffith's epitaph for Operation Dixie: “That 'race mixing' translated as communism in the view of Southern political and business leaders was a problem. That it translated in precisely the same way for vast numbers of Southern [white] workers was more than a problem: it threatened the CIO's entire undertaking."

Sugrue sees the post-war era and the succeeding decade as a time of complexity and contradiction in the realm of race relations, and argues that "many important questions remain unanswered". I agree. But complexity need not suggest the absence of coherence; nor is the fact of contradiction incompatible with a larger pattern. By looking briefly at

2 Robert Griffith, "Forging America's Postwar Order: Domestic Politics and Political Economy in the Age of Truman", in Michael J. Lacey (ed.), The Truman Presidency (Cambridge, 1989), pp. 57-88; Elizabeth Fones-Wolf, Selling Free Enterprise: The Business Assault on Labor and Liberalism, 1945-60 (Urbana, 1994); Nelson Liechtenstein. The Most Dangerous Man in Detroit: Walter P. Reuther and the Fate of American Labor (New York, 1995), pp. 226-240.

${ }^{3}$ Barbara S. Griffith, The Crisis of American Labor: Operation Dixie and the Defeat of the CIO (Philadelphia, 1988), p. 77. 
a number of examples from the steel and maritime industries, we can see the reality of complexity but also discern the existence of a clear pattern of development. It is a pattern that rank-and-file workers and their unions played an important role in shaping.

In steel, hiring was the prerogative of the companies, and over time they created a complex mosaic in the mills that reflected decades of ethnic and racial segmentation. Even in the non-union era workers played a role in the creation of this mosaic. A Polish immigrant in Pittsburgh noted the existence of "a Ukrainian department, a Russian department, [and] a Polish department", and judged it "a beautiful thing". Although the coming of industrial unionism led the companies to reaffirm their sole right to hire, they continued to collude with workers in maintaining long-standing patterns of hiring and job assignment.

The observations of a local union official at the Bethlehem Steel plant in Steelton, Pennsylvania, provide a fascinating portrait of how this pattern evolved in northern mills; they also offer tantalizing insights into the change from a predominantly ethnic pattern of collective identity and job segmentation to one in which "Negro" and "white" became the only dividing line that mattered. Joseph Bazdar, the local union president in Steelton, observed in 1950 that "prior to the organization of our plant the range of jobs open to minority groups was very limited. In many departments it was necessary for workers belonging to the 'wrong' group to curry favor with their foremen by plying them with material gifts, including cash, or by the old fashioned method known as 'bootlicking[,]' in order to retain even the lowest paid and most menial of jobs." In Steelton, the "wrong", or "minority", groups included not just black workers but recent immigrants and their sons, "workers of the wrong religious denomination, workers who did not belong to certain fraternal lodges and even workers who did not live in the same neighborhood as their foreman". By 1950, however, there had been an "appreciable change in the status of the majority of these workers". Apparently, the divisions between "foreigners" and "Americans" had significantly diminished, and even the recent immigrants had left their minority status behind. In the process, the long-standing barriers to their upward mobility within the plant's occupational hierarchy had been "largely wiped out".

For African-American workers in Steelton the old barriers remained in place, but Bazdar's portrayal of the relations between blacks and whites in the workplace was anything but simple. He asserted that "a definite ceiling exists on job opportunities for the majority of our negro workers slightly above the floor". At this level blacks and whites were "continuing to work in perfect harmony". It was at the higher levels

\footnotetext{
4 John Bodnar, Roger Simon and Michael P. Weber, Lives of Their Own: Blacks, Italians, and Poles in Pitusburgh, 1900-1960 (Urbana, 1982), p. 62.
} 
that problems existed, and he blamed them on the company; on the local union, which had been "lackadaisical in its approach to this problem"; and on white workers who were dependent on the day-to-day assistance of "negro helpers", but fearful that these same workers would "encroach" upon jobs that whites wished to safeguard as their own. In a statement that marked him as a rarity in the United Steelworkers (USWA), Bazdar admitted that the problem of racial discrimination was "becoming more acute with each passing day"."

In Youngstown, local union president Sam Camens offered a similar portrait of race relations at the Ohio Works of US Steel. Camens believed that overall the problem of discrimination at the plant stemmed from "Company hiring practices"; and, he declared, "There is nothing in our contract that can force the employment office to change these practices." He readily acknowledged, however, that the union's task was complicated by the fact that there was active rank-and-file resistance to the entry of blacks into certain departments and to their upgrading in other departments where they were concentrated in the less skilled jobs. Thus, he said, "the broad gauge [railroad] is strictly discriminatory, with only white employees. There is definite resistance on the part of management, and even our union membership, to breaking down this Jim Crow set-up." Similarly, the rolling mills were "strictly Jim Crow"; and "all the [craft] shops in our plant, as elsewhere throughout the district[,] are Jim Crow outfits, due to the hiring practices of management" and the "strong" acquiescence of white union members in this discriminatory pattern.

Bazdar and Camens made their observations as part of a survey that the international union's Committee on Civil Rights conducted in February and March 1950. The survey revealed a number of cases where aggressive action by local unions - sometimes in the face of rank-and-file resistance - led to increased opportunities for black workers. But in spite of detailed and painfully honest reports like Bazdar's and Camens', the committee chose to conclude that where racial discrimination existed, it was largely the result of "company discrimination on the hiring level a situation beyond the effective control of the union".

This complacent summation left enough unsaid to fill several volumes of testimony and analysis concerning the troubled history of racial discrimination in steel. ${ }^{8}$ While the union had no formal role in hiring, it

3 Joseph Bazdar to Thomas Shane, 9 March 1950, Folder 21, Box 3, Records of the United Steelworkers of America (USWA), Civil Rights Department, Historical Collections and Labor Archives, Pennsylvania State University, University Park, PA.

- Sam Camens to Thomas Shane, 10 March 1950, ibid.

7 United Steelworkers of America, Committee on Civil Rights, Sieelworkers Fight for Human Equality! (n.p., n.d.), pp. 15-17.

- One such volume is Richard L. Rowan, The Negro in the Steel Industry, part 4 of Herbert R. Northrup et al., Negro Employment in Basic Industry: A Study of Racial Policies in Six Industries (Philadelphia, 1970). 
did negotiate seniority agreements at the local level, and these documents tended to institutionalize historic patterns of racial inequality. Seniority in steel was not plantwide; often it was not even departmental but was based upon "lines of progression" within departments. Although the most egregious examples of discrimination occurred in Alabama and other southern states, by and large there was no Mason-Dixon line in steel. In keeping with the larger pattern nationwide, segregation in southern mills was de jure - that is, openly sanctioned by collective bargaining agreements - while in the North it was "merely" de facto. Jobs and lines of progression were not openly designated as black or white in northern mills as they often were in the South. But the combination of long-standing company hiring practices and unionnegotiated seniority agreements had essentially the same effect in the North that the more explicit forms of racial identification had in the South. Black workers were - in Herbert Hill's words - "locked in" to specific departments or lines of progression, in Buffalo as well as Birmingham. Even when they won the right to transfer to a new and better department or job ladder, they could not carry their accumulated seniority with them. As long as seniority agreements were negotiated locally, and as long as white rank-and-filers were determined to maintain their advantaged position in the mills' occupational hierarchy, USWA contracts would tend to "freeze" African Americans into low-paying, dead-end jobs. ${ }^{9}$

In assessing this situation, black workers and their allies in organizations such as the NAACP did not regard organized labor as weak and powerless. On the contrary, they became increasingly frustrated with the failure of unions to use the resources at their command to make good on their oft-stated commitment to racial equality. In the 1960 s and 1970s, black workers often turned to federal courts and administrative agencies such as the Equal Employment Opportunity Commission (EEOC) to challenge the discriminatory practices of companies and unions; and, again and again, the courts and the EEOC validated their contention that both management and labor were responsible for these practices.

Sugrue is correct to point out that in general companies were responsible for hiring new employees, and that neither unions nor rank-and-file workers exercised much direct influence in this arena. But what about

'Herbert Hill to Roy Wilkins ("Memorandum Re: United States Steel Corporation and United Steelworkers of America, AFL-CIO [,] Birmingham, Alabama"), 13 September 1965, Box A195, Group III, Records of the National Association for the Advancement of Colored People (NAACP), Manuscript Division, Library of Congress, Washington, DC; Herbert Hill, "Black Workers, Organized Labor, and Title VII of the 1964 Civil Rights Act: Legislative History and Litigation Record", in Herbert Hill and James E. Jones, Jr (eds), Race in America: The Struggle for Equality (Madison, 1993), pp. 309313. 
those instances where unions and their membership did have such power? We know about the building trades. As Roy Wilkins said in 1962, "a Negro worker needs the patience of Job, the hide of an elephant plus a crowbar to get into [AFL-CIO President George] Meany's own union the plumbers". ${ }^{10}$ We know, too, about the record of the UAW skilled trades, where, despite Walter Reuther's frequent protestations of good faith, black workers constituted less than 1 per cent of the skilled labor force in Detroit auto plants in $1960 .{ }^{11}$ But I want to return momentarily to the West Coast waterfront, where members of the Left-led International Longshoremen's and Warehousemen's Union (ILWU) controlled the hiring of dockworkers.

West Coast longshoremen were, by reputation, the "Lords of the Docks" - famous for their militancy, their left-wing politics, their control of the pace of work, their egalitarian distribution of job opportunities through union-controlled hiring halls. Before World War II, very few of these halls offered much work to African Americans, because black workers had constituted only 1.4 per cent of California's dock labor force in 1930, and the effect of the Great Depression was to diminish work opportunities even further. ${ }^{12}$

With its seemingly insatiable demand for labor, the war created a new terrain that offered numerous opportunities to test the union's egalitarian creed. In San Francisco, where the ILWU's left-wing leaders were concentrated, black workers entered the workforce in large numbers and became a substantial minority of the local union membership. The combination of a left-wing leadership and a critical mass of black workers pushed the San Francisco longshore local in the direction of racial progressivism. But in the other major ports on the West Coast - namely, Los Angeles, Portland and Seattle - the record was quite different.

When Nancy Quam-Wickham and I looked at the port of Los Angeles and began probing the record of San Pedro's Longshore Local 13, we found that the ILWU's fabled rank-and-file militancy could serve retrograde as well as progressive ends. Over the years, the membership of Local 13 used the instruments that the union's founding generation had forged in the 1930s to marginalize and, where possible, exclude African Americans. In this respect at least, Local 13 seems to have functioned like the AFL craft unions in the building trades, which used mechanisms such as control of apprenticeships and the dispatching of work to maintain not only a high degree of racial homogeneity but to reserve new jobs for the family and friends of current members. Local 13 had its

${ }^{10}$ Atlanta Daily, World, 23 November 1962, p. 5.

"Herbert Hill, "The Problem of Race in American Labor History" (paper presented at the Southem Historical Association annual meeting, New Orleans, 19 November 1995). p. 11.

12 Lester Rubin, The Negro in the Longshore Industry, The Racial Policies of American Industry, Report No. 29 (Philadelphia, 1970), pp. 136-141. 
own mechanism, "sponsorship", that served to accomplish the same end. To be a successful candidate for employment on the Los Angeles waterfront, one had to be sponsored by a member of Local 13, who exercised this right in order of seniority. Since the union assumed that a member would be likely to sponsor a "son, brother, neighbor, or friend", this practice "naturally" reinforced Local 13's pattern of racial exclusion. For with the exception of a small number of Mexican Americans, all of the local's most senior members were white; and in the residentially segregated and racially polarized environment of Los Angeles, a Local 13 member's "son, brother, neighbor, or friend" was likely to be white as well. ${ }^{13}$

Here, in a Left-led CIO union, is a case where workers exercised nearly full control of hiring. The power they exercised may have been exceptional, but their determination to defend the "wages of whiteness" was not. The difference between Sugrue and myself in assessing how this pattern developed is one of emphasis. But it is a difference, nonetheless. He argues that "the structures of racial discrimination were deeply resistant to change from the shop floor". My work has led me to conclude that while unions sometimes sought to change these structures, and in some instances succeeded in doing so, the predominant pattern was one in which employers and white workers colluded to maintain racial discrimination against black workers. However much they spoke the language of equal rights, unions usually acquiesced in the exercise of this racialized democracy.

Sugrue concludes that "what emerges from Nelson's article, above all, is a reminder of the varieties of racial discrimination and accommodation". I had hoped that would be the case. But Elizabeth Faue's response makes me wonder if she and Sugrue read the same article. She apparently sees no awareness of complexity on my part, no "attentive[ness] to the diversity of racial practices" (Sugrue's words), only a one-dimensional and monolithic denunciation of the white rank and file. Faue and I obviously disagree on a number of important points of historical interpretation. But in my judgement her "Anti-Heroes of the Working Class" does little to clarify those differences, largely because she insists on misrepresenting my argument and substituting accusations for analysis. Faue quotes my statement that "when we take race into account, the unionism of the white rank and file seldom looks progressive, and 'rank-and-file democracy' often becomes a means of protecting the position of the white majority against perceived threats from the black minority", and somehow manages to characterize it as a statement made

13 Nancy Quam-Wickham, "Who Controls the Hiring Hall? The Struggle for Job Control in the ILWU During World War II", in Steve Rosswurm (ed.), The ClO's Left-Led Unions (New Brunswick, 1992), pp. 47-67; Bruce Nelson, "Harry Bridges, the ILWU, and Race Relations in the CIO Era", Working Paper No. 2, Occasional Paper Series, Center for Labor Studies, University of Washington (Seattle, 1995), p. 15. 
"without modification". She completely ignores my assertion that white workers' "attitudes toward black demands for a greater measure of equality were not monolithic", as well as my contention that "our analysis must be based, finally, upon the attitudes and behavior of the majority of workers". ${ }^{14}$

Faue also accuses me of repenting of my "former enthusiasm for 'pentecostal' militancy". She is, for the most part, wrong in this accusation, but not entirely so. In my research on longshoremen, shipyard workers and steelworkers, I have found many instances where white rank-and-file militancy was aimed at excluding African Americans from the workplace, or, where that was not possible, limiting them to the lowest-paying and most disagreeable jobs. I do regard this kind of militancy as "suspect". More broadly, my research and my reading of the work of other scholars has convinced me that class struggle not only sharpens the lines between workers and employers but also accentuates divisions within the working class. This became especially evident to me when I looked at industrial workers, insurgent unionism and electoral politics in Detroit and the steel towns of Western Pennsylvania during the early years of the CIO. I no longer share the view that a "culture of unity" was developing at this time. ${ }^{15}$ On the contrary, the late 1930s in particular were characterized by an extraordinary combination of unity and fragmentation. The battles between the AFL and the CIO sometimes reached civil war proportions. While this conflict reflected the territorial ambitions of the warring labor federations, it was also driven by profound cultural differences that were rooted in ethnicity, race, religion and geography. In common with other segments of the populace, many workers were ambivalent about, sometimes deeply opposed to, what

14 Faue even manages a monumental distortion of the argument of my book, Workers on the Waterfront: Seamen, Longshoremen, and Unionism in the 1930s (Urbana, 1988). According to Faue, I argue therein that the progressive organizing activity of "cadres [...] ran repeatedly into grassroots resistance to change". In fact, that is the exact opposite of the book's argument. In my discussion of the famed West Coast maritime strike of 1934, for example, I state that "the Communist presence in the strike gave it a more disciplined and organized character and a more effective leadership [. . .] But the scope and dynamism of the conflict far exceeded the ability of the rather insignificant number of Communists to control or direct it. The fact is that the Big Strike was an authentic rank-and-file rebellion that had long been waiting to happen." Nelson, Workers on the Waterfront, p. 145; see also pp. 161-162, and passim.

${ }^{15}$ Bruce Nelson, "Auto Workers and Electoral Polities: The Detroit Municipal Election of 1937" (paper presented at the North American Conference on Labor History, Detroit, 19 October 1989); idem, "Reflections on Industrial Workers and Electoral Politics in the CIO Era" (paper presented at the Center for Labor-Management Policy Studies, Graduate School and University Center, City University of New York, 15 May 1990). See also Daniel Nelson, "The CIO at Bay: Labor Militancy and Politics in Akron, 1936-1938", Journal of American History, 71 (1984), pp. 565-586. The "culture of unity" argument has been developed most fully and impressively by Lizabeth Cohen, Making a New Deal: Industrial Workers in Chicago, 1919-1939 (Cambridge, 1990). 
Steve Fraser has called the "rational-materialist posture of the CIO leadership and its allies in the left wing of the Democratic party". Often, these workers were drawn to the leadership of shop-floor militants and, at the same time, were deeply influenced by the reactionary anti-semite, Father Charles Coughlin, whose radio sermons were a sacred part of the weekly routine in Catholic homes throughout industrial America. In his recent biography of Walter Reuther, Nelson Lichtenstein points out that as late as 1941 UAW leaders were opposed to electing the union's national officers by a referendum vote because they feared that this process would demonstrate the extent of Coughlin's influence among rank-and-file autoworkers. ${ }^{16}$

The evolution of the $\mathrm{CIO}$ was characterized by an increasingly sharp conflict between the ambitious and cosmopolitan agenda of labor liberals such as Reuther and the sense of necessity that propelled the struggle between shop-floor militants and management at the local level. Both groups of unionists claimed to believe in industrial democracy and, for me at least, the growing gap between their respective visions explains much of the unfulfilled promise of the CIO. But while my own sympathies have always been with the "syndicalists" on the shop floor, I have become more aware that grassroots insurgency can be a two-edged sword - driven by a logic of experience that embodies the democratic will of "the people", but reflective of local cultures that can be alternately progressive and reactionary. Shop-floor syndicalism was aimed at enhancing the power of workers vis-à-vis their employers; but often, especially when race became an issue, it was also aimed at enhancing the power of some workers at the expense of others.

It is not, then, a question of affirming or repudiating working-class militancy; nor does a simplistic dichotomy between "bureaucratic" and "community-based" unionism do much to increase our understanding of historical reality and present possibility. In her discussion of the CIO's racial practice, Faue makes a number of valid points but gets the dynamic that drove the process essentially wrong. She argues that "by the 1940s, CIO union leadership did not take seriously racism beyond the workplace". In fact, insofar as CIO leaders did take racial discrimination seriously, it was largely beyond the workplace (especially their own). For all of its heavy-handed paternalism, the United Steelworkers did

16 Steve Fraser, "The 'Labor Question"', in Steve Fraser and Gary Gerstle (eds), The Rise and Fall of the New Deal Order, 1930-1980 (Princeton, 1989), p. 73; Lichtenstein, The Most Dangerous Man in Detroit, p. 484. On Father Coughlin and the environment in which his world-view held sway, see Ronald H. Bayor, Neighbors in Conflict: The Irish, Germans, Jews, and Italians of New York City, 1929-1941 (Baltimore, 1978), pp. 87-108; Alan Brinkley, Voices of Protest: Huey Long, Father Coughlin, and the Great Depression (New York, 1982); Gerald H. Gamm, The Making of New Deal Democrats: Voting Behavior and Realignment in Boston, 1920-1940 (Chicago, 1989), pp. 137-159: Michael Kazin, The Populist Persuasion: An American History (New York, 1995), pp. 109-133. 
form a Committee on Civil Rights that was very active in the fight for fair employment practice legislation at the state and local level and in supporting the national agenda of organizations such as the NAACP. The NAACP's Herbert Hill, who would become one of the best informed and most persistent critics of organized labor's record on race, could still declare in 1954 that "in city after city Steelworkers are in the active leadership of the fight for civil rights". Speaking to the delegates at the USWA's biennial convention, Hill applauded the "long history of joint activity and cooperation between our respective organizations". In the United Auto Workers, Lichtenstein points out, Walter Reuther "sat on the board of directors of the NAACP, and almost all of the top UAW officers were life members of that organization. In Detroit the union turned over the entire regional apparatus - offices, phone banks, and mailing list - during the local NAACP chapter's annual membership drive." $" 17$

But, as Lichtenstein acknowledges, "Reuther was willing to go only so far". His handling of the demand for black representation at the top levels of the union was, at best, monumentally insensitive and inept; it largely reflected his determination to maintain full control of "his" union, and it compelled black UAW activists, even long-time veterans of the Reuther caucus, to turn outward, toward an alliance with organizations such as the NAACP and the Negro American Labor Council. Equally conspicuous was Reuther's timidity in addressing blatant examples of racial discrimination in the auto industry, especially in the skilled trades and in southern plants, where - with the full complicity of white unionists - blacks were often limited to janitorial jobs. Kevin Boyle points out that in the face of the South's "massive resistance" to racial change, the UAW leadership retreated into a policy of "gradualism" that was "dangerously close to appeasement". ${ }^{18}$

What stake did Reuther and, for that matter, the more conservative and complacent David McDonald of the Steelworkers have in the racebased occupational hierarchies that continued to predominate in so many of the plants in their jurisdiction? Essentially, none. Faue is correct to say that "any institutionalized practice of racism [. . . ] is the responsibility of leadership", but she is unwilling to acknowledge why leaders often acted as they did. As I argued in "Class, Race and Democracy in the CIO", the Reuthers and McDonalds had a clear interest in maintaining institutional equilibrium and were keenly aware that any real assault against racial discrimination on the shop floor would be dangerous to the stability of their organizations.

17 "Proceedings of the Seventh Constitutional Convention of the United Steelworkers of America" (Atlantic City, NJ, 20-24 September 1954), p. 163; Lichtenstein, The Most Dangerous Man in Detroit, pp. 315-316.

"Ibid., p. 316: Kevin Boyle. The UAW and the Heyday of American Liberalism, 19451968 (Ithaca, 1995), p. 126. 
Perhaps the greatest problem with Faue's "Anti-Heroes of the Working Class" is her invocation of the virtues of "community-based unionism" without any acknowledgement of the extent to which "community" and racial segregation have been virtually synonymous in twentieth-century America. Deeply-entrenched patterns of residential segregation have resulted from the intervention of many institutional actors. Realtors, bankers and even the federal government have often played a key role. But as Douglas Massey and Nancy Denton argue in American Apartheid, "the segregation of American blacks [. . .] was brought about by actions and practices that had the passive acceptance, if not the active support, of most whites in the United States". Arnold Hirsch's pathbreaking study of race and housing in Chicago accentuates the active support. Hirsch demonstrates that downtown corporate interests, University of Chicago liberals and white ethnics in the Windy City's vast bungalow belt were all equally determined to contain African Americans in the ghetto, even though the resources available to each group, and hence the tactics they used, differed significantly. ${ }^{19}$

A study of Chicago by William Kornblum makes it clear that some local industrial unions had close, even organic, ties to the residential neighborhoods that surrounded the factories and mills where their members worked. These were, in effect, "community-based unions". Their leaders may not have developed an agenda that sought to bridge the gap between the workplace and the home, but they maintained intimate ties with community institutions and their access to power in the union was based in significant measure on their prestige in the local community. Given the fierce determination of their neighbors and friends to exclude blacks from white neighborhoods, it is hardly surprising that local union leaders were unwilling to pursue a course that deviated significantly from the community's racial mores. ${ }^{20}$

When the United Auto Workers tried to do this in Detroit, in the 1949 mayoral election, many white union members supported Albert Cobo, a conservative, Republican real estate investor and corporate executive, against the UAW's own George Edwards. Race and housing were the key issues in this campaign, and Edwards' support for open housing made him unpalatable to the majority of blue-collar voters. In analyzing this election, Thomas Sugrue draws not only on the informed commentary of UAW political activists and other contemporaries but on the studies of voting patterns that the union conducted in selected precincts. ${ }^{21}$ And yet in the face of this evidence, Faue refuses to acknowledge a clear and compelling linkage "between the UAW rank and file

19 Douglas S. Massey and Nancy A. Denton, American Apartheid: Segregation and the Making of the Underclass (Cambridge, 1993), p. 15; Amold R. Hirsch, Making the Second Ghetto: Race and Housing in Chicago, 1940-1960 (Cambridge, 1983).

so William Kornblum, Blue Collar Community (Chicago, 1974), pp. 92-111.

${ }^{21}$ Sugrue, "Crabgrass-Roots Politics", pp. 570-571. 
and the racist turn in Detroit politics". Instead, she retreats to the ostrich-like assertion that "no one knows who the working class is any more".

A more fruitful approach would be to point out that, although there were occupational and income differences in voting patterns among whites, the introduction of racial issues in electoral campaigns tended to reduce this differential dramatically. A significant minority of the white union membership did follow the UAW's recommendations in the Detroit mayoralty election of 1949 . But the majority voted for candidates who promised to defend their racial interests. Even when these voters were willing to acknowledge the right of African Americans to adequate housing, they were more likely to embrace the argument of a local community activist who declared that "we have established a prior right to a neighborhood which we have built up through the years - a neighborhood which is entirely white and which we want kept white". ${ }^{22}$

This urgent call to defend the sanctity of "white" space became a central motif of American race relations, especially as the focus of the struggle for black equality shifted from the rural South to the urban North. In Parish Boundaries, John T. McGreevy has examined this conflict from the vantage point of the Roman Catholic Church and its immigrant, working-class parishes in cities such as Buffalo, Chicago, Detroit, Milwaukee, New York and Philadelphia. McGreevy never denies the reality of a deeply ingrained racism in the encounter between white ethnics and black migrants. But he also demonstrates that the response of Catholic parishioners and their pastors was profoundly influenced by values, traditions and interests that ranged from the long-term presence of "language" parishes, to the presumption that separate representation for various nationality and "racial" groups was entirely compatible with Catholic theology, to the Church's material interest in maintaining the property value of the extraordinary range of institutions it had constructed in the city. Above all, for generations of Catholics, neighborhood was defined by the boundaries of the parishes that were so central to their religious, educational and social lives, and urban turf thus became "sacred space". The defense of local communities, says McGreevy, was animated by a "vision with its own moral content". ${ }^{23}$

But this fact offered little if any solace to African Americans who found the increasingly suffocating confines of the ghetto intolerable and hence looked outward toward the white ethnic neighborhoods that surrounded them, in hopes of finding a more authentic "Promised Land". Hirsch tells the tragic story of Betty and Donald Howard, who moved

2 Ibid., p. 565.

23 John T. McGreevy, Parish Boundaries: The Catholic Encounter with Race in the Twentieth-Century Urban North (Chicago, 1996), quoted on pp. 78, 263. See also Eileen M. Mcklahon, Which Parish Are You From? A Chicago Irish Community and Race Relations (Lexington, 1995). 
into the Trumbull Park housing project in Chicago's solidly working-class, and Catholic, South Deering neighborhood in 1953. To look at, Betty Howard was "white"; at first her neighbors did not recognize her as African American. But her husband was darker-skinned, and soon the couple's presence at Trumbull Park generated a sustained wave of violent harassment. Betty Howard was also a Roman Catholic, and when she attended mass at St Kevin's Church, Donald Howard sat behind her with his "forty-five". It was, says Hirsch, a "less than comforting spiritual experience". The Howards soon left St Kevin's Church and Trumbull Park, but other black families remained and were compelled to endure "nearly a decade of sporadic violence". ${ }^{24}$

Trumbull Park raised troubling questions about the extent of the Church's authority in imposing policies that went against the grain of widely held beliefs. During the height of the conflict there, one local resident declared that "I'm a Catholic [...] and a good one I'd say. But the Church hasn't got a right to tell me who I should live next to." As the hierarchy strengthened its commitment to racial integration, and as many priests and nuns came to see direct participation in the civil rights movement as a vital form of Christian witness, the countercurrent of grassroots resistance to change grew proportionately. Thus, in the mid-1960s, when priests and nuns joined Martin Luther King, Jr in his controversial marches for open housing in Chicago, the residents of white, and mainly Catholic, neighborhoods responded with fury. They were particularly outraged at the presence of priests and nuns in the demonstrations. "You're not a real priest", spectators yelled; and as clergy and nuns marched side by side, their co-religionists shouted, "Hey Father, are you sleeping with her?" The questioning of the Church's authority extended even to Chicago's archbishop. Civil rights marchers encountered signs denouncing "Archbishop Cody and his commie coons", and one defender of the wages of whiteness declared that "Cody wasn't elected by us. He doesn't have the right to take away our rights."2s

The fact that an archbishop, whose exercise of authority was widely believed to be divinely ordained, could face such passionate resistance from the grassroots offers an illuminating comparison with the constraints facing the leadership of the CIO. Trade union officials were, after all, merely mortal, and unlike Archbishop Cody they could be removed from office by their constituents. Like him, however, they feared that the fruits of years of institution-building would unravel in the heat of racial conflict. "The rights of minorities are very important," said the

24 Arnold R. Hirsch, "Massive Resistance in the Urban North: Trumbull Park, Chicago, 1953-1966". Journal of American History, 82 (1995), pp. 522-550, quoted on Pp. 538, 522.

25 McGreevy, Parish Boundaries, pp. 100, 189, 190-191. 
president of a Steelworkers' local in Tennessee, "but they cannot be obtained or even preserved by action that might destroy our Local Union." ${ }^{26}$ This "common sense" would prevail again and again and the imperative of institutional survival would triumph over the union's commitment to racial equality.

Elizabeth Faue wants labor historians to provide the new leadership of the AFL-CIO with a "usable" past. But can intellectuals assist the struggles of working people by inventing a history that repeats the clichés, evasions and silences that have so often characterized organized labor's defense of its record on race? At a historical moment when conservative ideologues trumpet "the end of racism" and point to "black culture" as the principal source of racial inequality, it is much more important to shed light on the breadth and depth of the obstacles that African Americans have faced in their long-standing struggle for justice. ${ }^{27}$ Out of such an engagement with past and present realities, a surer sense of the way forward may come.

36 John Broome, "Regarding the appeal by colored members of Local 309", n.d., Folder 52, Box 7, USWA, Civil Rights Department.

${ }^{77}$ Among many examples, perhaps the most prominent is Dinesh D'Souza, The End of Racism: Principles for a Multicultural Society (New York, 1995). 